\title{
IMPLEMENTASIMODEL PEMBELAJARAN SIKLUS BELAJAR 5E TERHADAP PEMAHAMAN KONSEP MAHASISWA PGMIPAU PADA MATERI HUKUM DASAR KIMIA
}

\author{
Rody Putra Sartika ${ }^{1}$ \\ Prodi Pendidikan Kimia FKIP UNTAN \\ Email: \\ rodyputrasartika@gmail.com
}

\begin{abstract}
Abstrak
Penelitian ini bertujuan mendeskripsikan pemahaman konsep mahasiswa pada pembelajaran menggunakan model siklus belajar 5E materi Hukum Dasar Kimia.Bentuk penelitian adalahquasi experimental design dengan rancangan one group pretest-posttest design. Populasi dan sampel pada penelitian ini adalah mahasiswa PGMIPAUFKIP UNTAN Tahun Akademik 2014/2015 dengan menggunakan teknik sampling jenuh. Teknik pengumpulan data menggunakan pengukuran denganinstrumen tes hasil belajar.Teknik analisis data menggunakan analisis deskriptif kualitatif.Hasil penelitian diperoleh rata-rata pemahaman konsep mahasiswameningkat dengan kategori rendah berdasarkan skor gain ternormalisasi. Disimpulkan bahwa pemahaman konsep mahasiswa setelah melaksanakan pembelajaran yang menggunakan model siklus belajar 5E pada materi hukum dasar kimia mengalami peningkatan.
\end{abstract}

Kata kunci: Model siklus belajar 5E, pemahaman konsep, hukum dasar kimia.

\begin{abstract}
The aim of this study is to describe student conceptual understanding on learning cycle $5 E$ model on law of fundamental chemistry. one of quasi experimental design "One group pretest-postest design" was used in this study. Population and sample on this study are pgmipau fkip untan students on academic year of 2014/2015. Tes of student achievement was used to get data. Descriptive qualitative technique was used to analyze data. Result of this study is student conceptual understanding isimproved with low chategory according to normalized gain score. To conclude, student conceptual understanding after studying using learning cycle $5 E$ model on law of fundamental chemistry was improved.
\end{abstract}

Keywords: Learning cycle 5E, understanding of concepts, law of fundamental chemistry.

\footnotetext{
${ }^{1}$ Rody Putra Sartika adalah dosen Program Studi Pendidikan Kimia FKIP Untan
} 
Menurut BNSP (2006) mata pelajaran kimia bertujuan agar peserta didik memahami konsep prinsip, hukum, dan teori serta saling keterkaitan dan penerapannya untuk menyelesaikan masalah dalam kehidupan sehari-hari. Selama ini kimia merupakan salah satu mata pelajaran yang dianggap sulit bagi peserta didik. Faktor penyebab kesulian belajar kimia antara lain konsep kimia yang bersifat abstrak dan kurangnya kompetensi pendidik dalam penguasaan metode dan menggunakan model pembelajaran (Ashadi, 2009). Disamping itu, keabstrakan pada kimia semakin sulit dipahami dengan adanya konsep yang berlawanan dengan intuisi menjadikan kimia sebagai pelajaran yang kompleks, sehingga menyebabkan banyak kesulitan bahkan miskonsepsi pada mahasiswa.

Kesulitan ini salah satunya dapat ditemukan pada materi Hukum Dasar Kimia.Selama ini mahasiswa hanya memahami materi ini berdasarkan fenomena yang tampak saja. Sebagai contoh dapat ditemukan pada pratikum Kimia Dasar I dalammembuktikan Hukum Kekekalan Massa.Mahasiswa mengamati massa zat sebelum dan setelah bereaksi sama untuk reaksi yang tidak menghasilkan gas atau dilakukan pada wadah tertutup. Pada reaksi yang menghasilkan gas dan dilakukan pada wadah terbuka diperoleh massa zat sebelum dan setelah reaksi yang berbeda. Perbedaan massa zat sebelum dan setelah reaksi tersebut membuat mahasiswa berasumsi bahwa hukum kekekalan massa tidak terjadi pada reaksi tersebut, padahal apabila gas yang dihasilkan ditampung di dalam wadah dan di timbang massanya, maka akan memperoleh massa zat sebelum dan setelah reaksi yang sama.

Berdasarkan penjelasan di atas, sebagian besar pemahaman konsep mahasiswa pada materi hukum dasar kimia khususnya pada materi Hukum Kekekalan Massa masih belum utuh, padahal materi ini merupakan materi prasyarat yang harus dikuasai mahasiswa untuk memahami materi kimia selanjutnya, seperti Konsep Mol dan Larutan. Pembelajaran kimia diharapkan mampu memberikan pemahaman konsep yang utuh kepada mahasiswa salah satunya melalui pendekatan konstruktivis. Menurut Prawiradilaga (2009)konstruktivisme menyiapkan peserta didik untuk membentuk pemahaman dan pola pikir tersendiri. Pendekatan konstruktivis berpijak pada prinsip fundamental yang menganggap apa yang sudah diketahui peserta didik menjadi faktor utama dalam menentukan hasil dari pembelajaran dan menyediakan kesempatan kepada peserta didik untuk mengembangkan pemahaman baru dengan guru bertindak sebagai fasilitator pembelajaran daripada sebagai penyampai pengetahuan (Ausubel, 1968 dalam Gilbert \& Treagust, 2009).

Beberapa model pembelajaran dengan pendekatan konstruktivis yang dapat digunakan di dalam pembelajaran kimia salah satunya adalah model 
siklus belajar (learning cycle/LC). Model siklus belajar terdiri atas lima fase pembelajaran yang meliputi: Engagement, Exploration, Explanation, Elaboration, dan Evaluation(Lorsbach, 2002). Pada model siklus belajar 5E mahasiswa dapat mengidentifikasi suatu pola keteraturan dalam fenomena yang diselidiki, kemudian memperkenalkan konsep-konsep yang ada hubungannya dengan fenomena yang diselidiki dan mendiskusikannya dalam konteks apa yang telah diamati, selanjutnya menggunakan konsep-konsep yang telah diperkenalkan pada situasi baru. Siklus belajar merupakan model pembelajaran berbasis penelitian yang dapat membantu peserta didik mengeksplorasi konsep dalam sains dan membantu pendidik saat mereka merencanakan pelajaran yang dimaksudkan untuk fasilitasi yang bermakna dan pemahaman yang mendalam mengenai konsep yang diajarkan (Duran, Duran, Haney, \& Scheuermann, 2011).

Pada penerapan di kelas, model siklus belajar5E dirangkai dalam lima fase kegiatan. Fase engagement dilakukan dengan membuat koneksi ke pengalaman masa lalu dan mengekspos miskonsepsi mahasiswa dan mereka harus mengurangi ketidakseimbangan kognitif yang terjadi. Fase exploration dilakukan dengan membangun pengalaman dosen dan mahasiswa yang dapat digunakan kemudian untuk memperkenalkan dan mendiskusikan konsep, proses, atau keterampilan. Lembar Kerja Mahasiswa (LKM) dapat digunakan pada fase ini untuk membantu proses awal merumuskan konsep yang memadai dan akurat. Menurut Cooperstein \& Kocevar Weidinger (2004) konsep-konsep abstrak menjadi berarti, ditransfer, dan disimpan karena mereka terikat dengan kinerja dari suatu kegiatan. Pada fase exploration dapat mengarahkan pada penemuan konsep yang diajarkan dan dapat membangun makna dari konsep tersebut.

Fase explanation dilakukan dengan meminta mahasiswa menjelaskan pengalaman eksplorasi dan pengalaman engagement mereka dengan menggunakan istilah umum. Fase elaboration dilakukan dengan melibatkan mahasiswa dalam situasi baru dan masalah yang memerlukan transfer penjelasan yang indentik atau mirip. Melalui pengalaman baru, mahasiswa mengembangkan pemahaman yang lebih mendalam dan lebih luas serta informasi dan keterampilan yang memadai. Fase evaluation dilakukan dengan memberikan penilaian terhadap pengetahuan, pemahaman konsep, atau kompetensi mahasiswa dalam konteks baru yang kadang-kadang mendorong mahasiswa belajar melakukan investigasi lebih lanjut, dengan cara refleksi pelaksanaan pembelajaran.

Beberapa hasil penelitian para ahli menunjukkan bahwa penggunaan siklus belajar dapat memperjelas proses berpikir peserta didik dan memperbaiki miskonsepsinya(Balci, Cakiroglu, \& Tekkaya, 2006). Menurut 
Abraham \& Renner (1986); Beeth \& Hewson (1999); Gerber, Cavallo, \& Marek (2001); McComas (1992) dalam Hanuscin \& Lee (2008) siklus belajar dapat menghasilkan prestasi yang lebih baik dalam sains, retensi konsep yang lebih baik, meningkatkan sikap terhadap sains dan pembelajaran sains, meningkatkan kemampuan penalaran, dan keterampilan proses yang unggul daripada dengan pendekatan pembelajaran tradisional. Pembelajaran yang menggunakan model siklus belajar 5E (Engagement, Exploration, Explanation, Elaboration, dan Evaluation) dalam mengajarkan materi hukum dasar kimia diharapkan dapat meningkatkan pemahaman konsep mahasiswa. Berdasarkan penjelasan di atas, perlu dilakukan pembelajaran menggunakan model siklus belajar 5E pada materi Hukum Dasar Kimia untuk meningkatkan pemahaman konsep mahasiswa. Tujuan pada penelitian ini untuk mendeskripsikan pemahaman konsep mahasiswa pada pembelajaran menggunakan model siklus belajar 5E materi Hukum Dasar Kimia.

\section{Metode}

Penelitian ini termasuk jenis penelitian eksperimen bentukquasi experimental designdengan rancangan penelitian one group pretest-posttest design. Populasi dan sampel pada penelitian ini adalah mahasiswa PGMIPAUFKIP UNTANTahun Akademik 2014/2015 dengan menggunakan teknik sampling jenuh. Menurut Sugiyono (2013) teknik sampling jenuh adalah teknik penentuan sampel apabila semua anggota populasi digunakan sebagai sampel.Teknik pengumpulan data yang digunakan adalah pengukuran untuk mengetahui pemahaman konsep mahasiswa menggunakan instrumen tes hasil belajar.Teknik analisis data menggunakan analisis deskriptif kualitatif.

\section{Hasil dan Pembahasan}

\section{Hasil Belajar Mahasiswa}

Hasil belajar mahasiswa diperoleh dari tes hasil belajar yang dilakukan sebanyak dua kali, yaitu tes awal (pretest) untuk mengetahui kemampuan awal mahasiswa sebelum diberikan perlakuan dan tes akhir (posttest) untuk mengetahui pemahaman konsep mahasiswa setelah diberikan perlakuan dengan menggunakan model siklus belajar pada materi Hukum Dasar Kimia. Hasil reabilitas instrumen tes hasil belajar menunjukkan bahwa instrumen yang digunakan dapat dipercaya sebagai alat pengumpul data dengan kategori rendah. Indeks sensitivitas efek pembelajaran yang diperoleh mulai dari 0 hingga 0,48 , dalam hal ini nilai-nilai positif yang lebih besar akan menunjukkan item dengan sensitivitas yang lebih besar terhadap efek dari pembelajaran. Pada item soal 1, 3, 4, 5 dan 6 memiliki sensitivitas di bawah 
0,3.Rendahnya indeks sentivitas yang diperoleh kelima item soal tersebut disebabkan karena pada posttest sebagian besar mahasiswa tidak benar dalam menjawab item soal tersebut atau jawaban soal yang diberikan masih belum utuh walaupun telah diberikan perlakukan.Mahasiswa dalam memperoleh konsep belum seutuhnya dapat melakukan proses asimilasi dan akomodasi, sehingga penguasaan konsep masih belum luas dan mendalam. Menurut Ibrahim (2012) penguasan konsep dengan baik, luas dan mendalam seperti yang dimiliki oleh pakar bidang ilmu tertentu, memungkinkan seseorang atau pakar yang bersangkutan menerapkan penguasaannya dalam berbagai keperluan.

Berdasarkan hasil pretest diperoleh pada ketuntasan individual, tidak ada satupun mahasiswa yang mencapai kriteria ketuntasan minimum (KKM) yang ditetapkan sebesar 75 untuk materi Hukum Dasar Kimia, hal ini berarti ketuntasan klasikal sebesar $75 \%$ tidak tercapai.Rata-rata ketercapaian indikator pembelajaran $<75 \%$ kecuali pada item soal nomor 3 (indikator 1) yang dapat dilihat pada Tabel 1.

Tabel 1. Rata-rata ketuntasan indikator pada pretest

\begin{tabular}{ccccccc}
\hline Indikator & \multicolumn{1}{c}{} & \multicolumn{2}{c}{$\mathbf{2}$} & \multicolumn{2}{c}{$\mathbf{3}$} \\
\hline Soal & $\mathbf{1}$ & $\mathbf{3}$ & $\mathbf{2}$ & $\mathbf{5}$ & $\mathbf{4}$ & $\mathbf{6}$ \\
\hline $\begin{array}{c}\text { Persentase } \\
\text { ketuntasan } \\
\text { indikator } \\
\text { klasikal }\end{array}$ & 5,3 & 81,3 & 26,7 & 2,7 & 5,3 & 4,0 \\
\cline { 2 - 7 } & 43,3 & 14,7 & & 4,7 \\
\hline
\end{tabular}

Tidak tercapainya ketuntasan individual dan/atau rendahnya rata-rata ketercapaian indikatorkarena dalam menjawab soal pretest mahasiswa hanya menggunakan skema awal yang terdapat dipikirannya, dengan didasarkan pada hasil kesimpulan dari pemikiran pada saat mereka menjawab soal tersebut.

Mahasiswa dalam menjawab soal pretest hanya menggunakan konsepsi awal (prakonsepsi) yang dimilikinya untuk materi Hukum Dasar Kimia berdasarkan pada pengetahuan yang pernah diperolehnya semasa SMA atau berdasarkan intuisi maupun pengalaman sehari-hari. Menurut Lucariello (2013) peserta didik tidak datang ke sekolah sebagai papan tulis kosong untuk diisi dengan pengajaran, sebaliknya, mereka datang ke sekolah dengan pengetahuan yang cukup, beberapa benar dan beberapa tidak, baik pengetahuan didasarkan pada intuisi, pengalaman sehari-hari, serta apa yang sudah diajarkan pada mereka dalam setting lainnya. 
Sebagian dari pemahaman tersebut sesuai dengan pemahaman yang dimiliki dan diyakini kebenarannya oleh para ilmuwan (sesuai dengan konsep ilmiah), akan tetapi banyak juga diantara pemahaman yang dimiliki seseorang sama sekali berbeda dengan konsep ilmiah yang diakui kebenarannya (Ibrahim, 2012).

Hasil posttest diperolehhampir semua soal mengalami peningkatan presentase, kecuali pada soal nomor 5. Berdasarkan persentase ketuntasan indikator, semua mahasiswabelum mencapai kriteria ketuntasan minimum (KKM) yang ditetapkan sebesar 75 untuk materi Hukum DasarKimia, sehingga ketuntasan secara klasikal belum tercapai. Berdasarkan rata-rata ketercapaian indikator $<75 \%$ kecuali pada item soal nomor 3 (indikator 1), yang dapat dilhat pada Tabel 2.

Tabel 2.Rata-rata ketuntasan indikator pada posttest

\begin{tabular}{ccccccc}
\hline Indikator & \multicolumn{1}{c}{$\mathbf{1}$} & \multicolumn{2}{c}{} & \multicolumn{2}{c}{$\mathbf{3}$} \\
\hline Soal & $\mathbf{1}$ & $\mathbf{3}$ & $\mathbf{2}$ & $\mathbf{5}$ & $\mathbf{4}$ & $\mathbf{6}$ \\
\hline $\begin{array}{c}\text { Persentase } \\
\text { ketuntasan } \\
\text { indikator } \\
\text { klasikal }\end{array}$ & 9,3 & 82,7 & 72,0 & 1,3 & 40,0 & 6,7 \\
\cline { 2 - 7 } & 46 & 36,67 & \multicolumn{2}{c}{23,3} \\
\hline
\end{tabular}

Tingginya rata-rata ketercapaian item soal nomor 3 pada indikator 1 dapat disebabkan karena mahasiswa telah memperoleh keterampilan prasyarat (subordinate skills) yang diperoleh dari materi sebelumnya, yaitu materi persamaan reaksi. Keterampilan prasyarat yang diperoleh mahasiswa pada materi sebelumnya telah menjadi skemata untuk memahami konsep baru melalui proses asimilasi dan akomodasi. Menurut Arends (2008) asimilasi terjadi apabila individu memasangkan insformasi baru dengan skemata yang sudah ada, sedangkan akomodasi terjadi apabila individu mengubah skemata yang sudah ada untuk merespon ide atau situasi baru.

Rendahnya rata-rata ketercapaian indikator bahkan pada soal nomor 5 (indikator 2) terjadi penurunan persentase,karena materi pada indikatortersebut bersifat abstrak dan berdasarkan data-data praktikum, sehingga konsep yang dipelajari mahasiswa menjadi lebih kompleks dan memerlukan pemahaman konsep yang utuh.Menurut Silaholo (2008) Suatu konsep kompleks hanya dapat dikuasai dengan baik dan benar bila konsepkonsep yang mendasari telah dikuasai dengan baik dan benar pula.Menurut Dahar (1996) tingkat-tingkat pencapaian konsep yang diharapkan tercermin dari tujuan-tujuan yang dirumuskan bagi peserta didik.Tidak tercapainya ketuntasan individual dari mahasiswa dapat disebabkan karena terdapat 
beberapa indikator pembelajaran yang belum tercapai, di mana dapat terjadi kesalahan pemahaman terhadap suatu konsep oleh mahasiswa.

Menurut Ibrahim (2012) kesalahan konsep dapat terjadi karena: 1) Penguasaan konsep oleh peserta didik belum lengkap, sederhana dan berbeda; 2) Karena ketidakmampuan peserta didik membedakan atribut (ciri penentu) dari sejumlah ciri umum yang dimiliki oleh sebuah konsep; 3) Miskonsepsi terjadi karena peserta didik tidak menguasai konsep prasyarat dari suatu konsep tertentu; 4) Jumlah atribut yang relevan dan tidak relevan, yang digunakan ketika mengajar konsep juga mempengaruhi tingkat kesulitan memperoleh/memahami suatu konsep; 5) Istilah seharihari yang dijumpai pertama kali oleh peserta didik di dalam bahasa Ibunya, juga mempengaruhi kesalahan konsep; 6) Beberapa sumber belajar yang digunakan peserta didik untuk belajar konsep juga memiliki kontribusi dalam meningkatkan miskonsepsinya.

2. Pemahaman Konsep Mahasiswa

Pemahaman konsep mahasiswa terhadap materi Hukum Dasar Kimia diperoleh dari tes hasil belajar yang terdiri atas 3 indikator dan dijabarkan ke dalam 6 soal essay dengan rentang kriteria soal C4 (menganalisis).Berdasarkan nilai dari skor gain ternormalisasi diperoleh mahasiswa berada pada rentang 0-0,6, sehingga dapat dikatakan peningkatan pemahaman konsep mahasiswa berada kategori sedang dan rendah. Secara klasikal diperoleh rata-rata peningkatan pemahaman konsep mahasiswa berada pada kategori rendah, yang dapat dilihat pada Tabel 3.

Tabel 3. Rata-rata skor gain ternormalisasi

\begin{tabular}{cccc}
\hline $\begin{array}{c}\text { Skor } \\
\text { Pretest }\end{array}$ & $\begin{array}{c}\text { Skor } \\
\text { Posttest }\end{array}$ & $\begin{array}{c}\text { Skor gain } \\
\text { ternormalisasi }\end{array}$ & Kategori \\
\hline $\mathbf{1 , 8 8}$ & 3,18 & 0,18 & Rendah \\
\hline
\end{tabular}

Berdasarkan Tabel 3,prakonsepsi mahasiswa telah mengalami perubahan setelah diberikan pembelajaran dengan mengunakan model siklus belajar 5E pada materi Hukum Dasar Kimia, walaupun perubahan yang terjadi masih berada pada kategori rendah. Menurut Ibrahim (2012) prakonsepsi akan berubah manakala peserta didik yang bersangkutan diajarkan konsep yang sebenarnya.

Terjadinya peningkatan pemahaman konsep sebagian besar mahasiswa karena telah diajarkan menggunakan model siklus belajar 5E pada materi Hukum Dasar Kimia. Model siklus belajar 5E yang digunakan di dalam penelitian ini merupakan model pembelajaran yang membuat mahasiswa menjadi aktif dan memberikan pengalaman langsung dalam mempelajari kompetensi-kompetensi yang ingin dicapai. Model ini terdiri 
atas lima fase pembelajaran yang meliputi: fase engagement, fase exploration, fase explanation, fase elaboration dan fase evaluation. Fase engagement, membuat hubungan antara pengalaman belajar mahasiswa pada masa lalu dan saat ini, dengan terlebih dahulu mengungkap konsepsi mahasiswa melalui pertanyaan-pertanyaan dari fenomena yang ditemukan di dalam kehidupan sehari-hari sesuai dengan konsep yang akan dipelajari. Pada fase ini terjadi proses asimilasi dimana mahasiswa menggunakan struktur kognitif yang sudah ada untuk merespon informasi baru yang diterimanya, sehingga dapat mengurangi ketidakseimbangan kognitif yang terjadi dan secara aktif termotivasi dalam pembelajaran.

Setelah melakukan fase engagement, selanjutnya mahasiswa mengeksplorasi ide-ide melalui fase exploration.Fase ini membangun pengalaman mahasiswa untuk memperkenalkan dan mendiskusikan konsep dengan bantuan lembar kerja mahasiswa (LKM). Di dalam LKMmahasiswa difasilitasi untuk menyelesaikan kegiatan praktikum yang membantu mereka menggunakan pengetahuan sebelumnya untuk menghasilkan ide-ide baru dan mengeksplorasi pertanyaan-pertanyaan yang muncul sehingga memulai proses keseimbangan. Dalam hal ini, tidak semua konsep baru dapat diasimilasi ke dalam skema yang telah dimiliki mahasiswa yang pada akhirnya terjadi proses akomodasi. Proses keseimbangan diperlukan untuk mengatur keseimbangan antara proses asimilasi dan akomodasi, sehingga mahasiswa dapat menyatukan konsep baru yang diterimanya dengan struktur kognitif yang telah ada (skemata). Menurut pemikiran Piaget pengetahuan tidak statis, tetapi terus berkembang dan berubah secara konstan selama peseerta didik mengkonstruksi pengalaman-pengalaman baru yang memaksa mereka untuk membangun dan memodifikasi pengetahuan sebelumnya (Arends, 2008).

Pada fase exploration mahasiswa dibentuk ke dalam kelompok heterogen yang dapat membantu mahasiswa secara aktif membangun konsep-konsepnya sendiri dengan cara berinteraksi dengan lingkungan sosialnya, baik dengan bimbingan dari dosen maupun kerjasama dengan teman sebayanya dalam satu kelompok dalam melaksanakan praktikum sesuai dengan LKM yang diberikan. Menurut pemikiran Vygotsky interaksi sosial dengan orang lain memacu pengkonstruksian ide-ide baru dan meningkatkan perkembangan intelektual peserta didik. Di samping itu, Bruner juga menekankan pentingnya membantu peserta didik untuk memahami struktur atau ide-ide kunci suatu disiplin ilmu, kebutuhan akan keterlibatan aktif peserta didik dalam proses belajar, dan keyakinan bahwa 
pembelajaran sejati terjadi melalui personal discovery (penemuan pribadi) (Arends, 2008).

Fase explanation mendorong mahasiswa untuk menjelaskan pemahaman konsep yang telah diperoleh pada fase engagement dan fase explaration dengan kalimat mereka, meminta bukti dan klarifikasi dari penjelasan mereka dan mengarahkan pada kegiatan diskusi.Melalui fase ini mahasiswa dapat menemukan istilah-istilah dari konsep yang telah dipelajari. Menurut Byber, Taylor, Gardner, Pamela Van Scotter, \& Landes (2006) penjelasan dari pendidik atau kurikulum dapat membimbing mereka menuju pemahaman yang lebih dalam, yang merupakan bagian penting dari fase ini. Dengan demikian diharapkan dapat mereduksi kesalahankesalahan konsep yang terjadi dan mahasiswa dapat memperoleh pemahaman konsep yang utuh.

Fase elaboration memfasilitas transfer konsep untuk situasi yang sama tetapi baru dengan bantuan LKM lanjutan. Mahasiswa melakukan praktikum lanjutan sesuai dengan LKM lanjutan yang diberikan untuk mengembangkan pemahaman konsep yang lebih dalam dan luas. Melalui diskusi kelompok dan situasi pembelajaran yang kooperatif dapat memberikan kesempatan pada siswa untuk mengekspresikan pemahaman mereka tentang materi yang dipelajari. Fase ini memberikan kesempatan kepada mahasiswa untuk terlibat dalam situasi dan masalah baru yang memerlukan transfer penjelasan yang indentik. Dengan demikian pembelajaran menjadi lebih bermakna karena mahasiswa diharapkan mampu mengaitkan situasi dan masalah baru dengan struktur kognitif yang telah ada.Menurut pemikiran Ausabel makna dapat muncul dari materi baru hanya bila materi itu terkait dengan struktur kognitif dari pembelajaran sebelumnya (Arends, 2008).Fase terakhir pada model siklus belajar adalah evaluation yang merupakan kesempatan bagi dosen untuk menilai pemahaman konsep mahasiswa.Mahasiswa diminta untuk mengerjakan latihan soal di dalam LKM untuk mengetahui pemahaman konsep pada materi hukum dasar kimia.

Berdasarkan skor gain ternormalisasimasih ditemukan 3 orang mahasiswa yang tidak mengalami peningkatan hasil belajar. Hasil wawancara yang dilakukan peneliti diperoleh bahwa mahasiswa tersebut lupa konsep dari materi yang dipelajari. Hasil wawancara di atas menunjukkan bahwa pemahaman konsep mahasiswa tersebut masih belum utuh, padahal untuk menguasai konsep yang kompleks dengan baik dan benar, perlu memahami konsep tersebut secara utuh yang memerlukan komitmen waktu dan usaha dari mahasiswa tersebut. Penerapan pembelajaran menggunakan model siklus belajar 5E, memberikan 
mahasiswa kesempatan berperan aktif untuk menggali dan memperkaya pemahaman akan konsep-konsep yang mereka pelajari.

\section{Simpulan dan Saran}

Berdasarkan hasil penelitian dan pembahasan serta temuan-temuan di dalam penelitian, dapat disimpulkan bahwa pemahaman konsep mahasiswa setelah pembelajaran menggunakan model siklus belajar 5E pada materi Hukum Dasar Kimia mengalami peningkatan. Berdasarkan hambatan yang ditemukan di dalam penelitian ini, diberikan saran sebagai solusi alternatif yaitu: Memberikan lebih banyak perhatian dan bimbingan kepada mahasiswa pada fase exploration dan fase elaboration, sehingga waktu diperlukan kedua fase tersebut dapat dimanfaatkan secara efektif. Pada kedua fase tersebut memerlukan waktu yang lebih lama untuk mahasiswa baru melakukan praktikum sesuai dengan lembar kerja mahasiswa (LKM) dan secara aktif membangun konsep secara mandiri (fase exploration) serta mengembangkan pemahaman konsep yang lebih dalam dan luas dalam situasi yang sama tetapi baru (fase elaboration).

\section{Daftar Pustaka}

Arends, R. L. (2008). Learning To Teach Edisi Ketujuh. Yokyakarta: Pustaka Pelajar.

Ashadi. (2009). Kesulitan Belajar Kimia bagi Siswa Sekolah Menengah. Dipetik Februari 2, 2014, dari http://pustaka.uns.ac.id/include/inc_ pdf.php?nid=198

Balci, S., Cakiroglu, J., \& Tekkaya, C. (2006). Enggagement, Exploration, Explanation, Extension, and Evaluation (5E) Learning Cycle and Conceptual Change Text as Learning Tools. Biochemistry and Molecular Biology Education, Vol. 34, No. 3, 199-203.Byber, R. W., Taylor, J. A., Gardner, A., Pamela Van Scotter, J. C., \& Landes, N. (2006). The BSCS 5E Instructional Model: Origins and Effectiveness. Colorado Springs: BSCS.

BNSP. (2006). Standar Isi untuk Satuan Pendidikan Dasar dan Menengah. Dipetik Februari 7, 2014, dari http://matematika.upi.edu/wpcontent/uploads/2013/02/Buku-Standar-Isi-SMA.pdf

Cooperstein, S. E., \& Kocevar Weidinger, E. (2004). Beyond Active Learning: a Constructivist Approach to Learning. Emerald Group Publishing Limited, 141-148. 
Dahar, R. W. (1996). Teori-Teori Belajar. Jakarta: Erlangga.

Duran, E., Duran, L., Haney, J., \& Scheuermann, A. (2011). A Learning Cycle for All Student. Ohio: Sci Links.

Gilbert, J. K., \& Treagust, D. (2009). Multiple Refresentation in Chemical Education. Australia: Springer.

Hanuscin, D. L., \& Lee, M. H. (2008). Using the Learning Cycle as a Model for Teaching the Learning Cycle to Preserve Elemtary Teacher. Journal of Elementary Science Education, Vol. 20. No. 2, 51-66.

Ibrahim, M. (2012). Konsep, Miskonsepsi dan Cara Pembelajarannya. Surabaya: Unesa University Press.

Lucariello, J. (2013). How Do My Students Think: Diagnosing Student Thinking (Understanding misperceptions is key early step). Retrieved Mei 23, 2012, from American Psycological Association: http://www.apa.org/ education/k12/student-thinking.aspx?item=1

Lorsbach, A. (2002). The Learning Cycle as A Tool for Planning Science Instruction. Dipetik Desember 10, 2002, dari http://www.coe.ilstu.edu/ scienceed/lorsbach/257lrcy.html.

Prawiradilaga, D. S. (2009). Prinsip Disain Pembelajaran. Jakarta : Kencana.

Sihaloho, M. (2008). Analisis Pemahaman Konsep Pergeseran Kesetimbangan Kimia pada Tingkat Makroskopis dan Mikroskopis siswa di SMA Negeri Gorontalo. Retrieved Oktober 14, 2012, from journal.ung.ac.id/ filejurnal/.../MSVol5No2_06.pdf: www.google.com

Sugiyono. (2013). Metode Penelitian Pendidikan Pendekatan Kuantitatif, Kualitatif dan $R \& D$. Bandung: Alfabeta. 